\title{
Foliar Applications of Acibenzolar-S-Methyl Negatively Affect the Yield of Grafted Tomatoes in Fields Infested with Ralstonia solanacearum
}

Sanju Kunwar, Mathews L. Paret, Joshua H. Freeman, Laura Ritchie, and Stephen M. Olson, North Florida Research and Education Center, University of Florida, Quincy, FL 32351; James Colee, Department of Statistics, University of Florida, Gainesville, FL 32611; and Jeffrey B. Jones, Department of Plant Pathology, University of Florida, Gainesville, FL 32611

\begin{abstract}
Three field experiments were conducted in Florida from 2012-2014 to assess the impact of acibenzolar-S-methyl (ASM), a systemic acquiredresistance inducer, applied as foliar spray or through drip-irrigation lines, on bacterial wilt incidence and yield of grafted tomatoes. The experiments were conducted in a field with race 1 , biovar 1 strain of Ralstonia solanacearum, causal agent of tomato bacterial wilt. In all three experiments, the susceptible tomato variety BHN 602, grafted onto a resistant rootstock BHN 998, was compared with nongrafted BHN 602, treated with or without foliar applications of ASM and with grafted plants treated with foliar applications of ASM. In two experiments, an additional

treatment of drip applications of ASM on grafted and nongrafted plants was evaluated. Grafting alone or in combination with drip applications of ASM $(178.6 \mu \mathrm{M})$ significantly reduced disease incidence and in creased total marketable yield relative to nongrafted treatments. There were no significant differences between grafted plants with or without drip ASM applications in terms of bacterial wilt incidence or total marketable yield. However, we demonstrate for the first time that foliar ASM applications on grafted plants negatively affects the total marketable yield compared with drip ASM applications on grafted plants or nontreated grafted control.
\end{abstract}

Fresh market tomato (Solanum lycopersicum Mill.) is an important vegetable crop in the United States, with a total harvested area of 38,162 ha and a farm value of $\$ 1.2$ billion (USDA-NASS 2016). Florida, one of the leading producers of fresh market tomatoes in the United States, contributed 36.5\% ( $\$ 453$ million) of the 2015 total tomato farm value in the United States (USDA-NASS 2016). However, tomato production in the southeastern United States, including Florida, is affected by bacterial wilt disease caused by Ralstonia solanacearum (Smith 1896, Yabuuchi et al. 1996 emend.) (Safni et al. 2014) (Ji et al. 2005; Jones et al. 2014; Hayward 1991, 1994; Hong et al. 2012; Mansfield et al. 2012). Ralstonia solanacearum is a soilborne bacterium belonging to the $\beta$ subdivision of proteobacteria. It was listed as the second most important bacterial plant pathogen in the world in terms of scientific and economic importance (Mansfield et al. 2012). The bacterium has a global distribution and a wide host range of more than 200 plant species in 50 different families (Hayward 1994). Major crop losses due to bacterial wilt disease have been reported from almost all tomato producing regions of the world including southeast United States. (Hayward 1991, 1994; Jones et al. 2014). Ralstonia solanacearum has the ability to survive extended periods of time in soil (Graham and Lloyd. 1979; Van Elsas et al. 2000) and water (Hong et al. 2008), and can also survive in the roots and rhizosphere of several weed hosts (Hong et al. 2008; Pradhanang et al. 2000). The worldwide distribution and extensive host range (Hayward 1991, 1994), complex genetic diversity (Fegan and Prior 2005), and the ability of the pathogen to survive in soil and water for an extended period of time make it difficult to manage bacterial wilt of tomato. In Florida, race 1 strains (biovar I, phylotype II) have been reported to cause more than $80 \%$ yield losses in open-field tomato production under disease favorable conditions (Hong et al. 2012).

Soil fumigation with methyl bromide and/or chloropicrin was used for decades to manage many soil-borne pathogens, including $R$. solanacearum (Enfinger et al. 1979; Ji et al. 2005; Santos et al. 2006). However, due to its ozone depleting potential, methyl bromide has been phased out through the establishment of the Montreal

Corresponding author: Mathews L. Paret; E-mail: paret@ufl.edu

Accepted for publication 16 January 2017.

C 2017 The American Phytopathological Society
Protocol (Santos et al. 2006; UNEP 2011). Currently, methyl bromide use is only allowed under critical use exemptions (King et al. 2008). Also, use of chloropicrin remains under strict regulation by the United States Environmental Protection Agency because of its toxic and volatile nature (Gan et al. 2000). Previous studies utilizing essential oils from thyme (Thymus spp.), palmarosa [Cymbopogan martini. (Roxb.) Wats.], and lemon grass [(Cymbopogon citratus (DC. ex Nees) Stapf.] were shown to be effective against a race 1, biovar $1 R$. solanacearum strain in tomato field experiments $(\mathrm{Ji}$ et al. 2005). However, the volatile nature, low soil retention, difficult field application, and high cost associated with these plant essential oils render them impractical for field applications. Crop rotation using cover crops has been studied as a potential tool for bacterial wilt management in North Florida (Momol et al. 2005). Even though this is a good tool for reducing initial inoculum, it is not highly effective due to the wide host range of the bacterium and is thus of limited value (McCarter, 1991). To date, the use of resistant cultivars has been identified as the most effective and practical method for managing bacterial wilt disease (Lebeau et al. 2011). Breeding programs conducted in Florida in the past have resulted in tomato genotypes that are moderately resistant to bacterial wilt, such as 'Neptune' and 'FL7514' (Scott et al. 1995). However, none of the commercial varieties, currently available in Florida and elsewhere in the United States have adequate resistance to bacterial wilt. Grafting using resistant rootstock has been demonstrated as one of the methods of improving tomato resistance to bacterial wilt with significant improvement in marketable yield (McAvoy et al. 2012; Rivard and Louws 2008). For example, bacterial wilt resistant rootstocks of tomato such as 'Cheong Gang', 'Jjak Kkung', 'RST-04-106-T', 'RST-04-105-T', 'Hawaii 7998', 'BHN 1053', 'BHN 1054', 'TMZQ702', and 'Dai Honmei', have been found to provide good success in the United States against $R$. solanacearum (McAvoy et al. 2012; Rivard et al. 2012). Use of rootstocks resistant to multiple pathogens offers a viable alternative for controlling several tomato diseases in the field. For example, the rootstock BHN 998, which was used in this study, has been found to impart resistance to both $R$. solanacearum (McAvoy et al. 2012) and root-knot nematode (Meloidogyne spp.) (Kunwar et al. 2015), two of the important tomato diseases in Florida. Apart from resistant rootstock, another method for improving plant resistance to combat plant diseases is to use plant activators also known as systemic acquired resistance (SAR) inducers. Acibenzolar-S-methyl [ASM; active ingredient: acibenzolar-S-methyl (1,2,3-benzothiadiazole-7-thiocarboxylic acidS-methyl-ester, 50\%) also know as Actigard 50 WG (Syngenta Crop 
Protection, Inc. Greensboro, NC)] is a SAR inducer, currently labeled on tomatoes in the United States against bacterial leaf spot (caused by Xanthomonas spp.) and bacterial speck (caused by Pseudomonas syringae pv. tomato), and bacterial diseases of other fruiting vegetables, cucurbits, and cole crops (Syngenta 2013; Tally et al. 1999; Vallad and Goodman 2004). ASM, when applied as a foliar spray, was found to improve tomato resistance to bacterial wilt disease and significantly improve yield in those genotypes moderately resistant to $R$. solanacearum, but had no effect on the susceptible genotypes (Pradhanang et al. 2005). Based on that study, we hypothesized that applying ASM onto the grafted plants may help improve the resistance of the rootstock and thus improve the overall resistance of the grafted plants to $R$. solanacearum. Even though grafting and applications of ASM have been independently shown to improve bacterial wilt management and yield in tomatoes, the impact of integrating these two strategies on bacterial wilt incidence and total marketable yield of tomato is not known. Soil application of SAR inducers has been previously demonstrated to provide better disease control than foliar applications. For example, Graham and Myers (2011) demonstrated that soil application of ASM or other SAR inducers such as Imidacloprid and Thiamethoxam provided better efficacy in reducing the severity of citrus canker in young grapefruit trees than did foliar applications. Thus, we hypothesized that drip applications of ASM may provide better control of bacterial wilt disease in comparison with foliar applications in grafted tomato plants. The objectives of this study were: (i) to investigate the effects of ASM applied as a foliar spray or through drip irrigation on the management of bacterial wilt disease on grafted tomato plants in the field infested with $R$. solanacearum; and (ii) to evaluate the effect of the integrated approach on total marketable yield.

\section{Materials and Methods}

Bacterial culture and inoculum preparation. A well-characterized R. solanacearum strain Rs5 (race 1, biovar 1, phylotype II, sequevar 7) isolated from tomato in Quincy, FL was used in the study (Ji et al. 2005, 2007). A pure culture of the bacterial strain was streaked on casamino acid peptone glucose (CPG) agar medium (Kelman, 1954) and incubated at $28^{\circ} \mathrm{C}$ for $48 \mathrm{~h}$. A suspension of the bacterial culture was then prepared in sterile deionized water and adjusted spectrophotometrically to $\mathrm{OD}_{600}=0.1$ corresponding to $\sim 10^{8}$ colony forming units $(\mathrm{CFU}) / \mathrm{ml}$. The resulting suspension was further diluted to $10^{5}$ or $10^{6} \mathrm{CFU} / \mathrm{ml}$ in sterile deionized water and used for field inoculations.

Field experiments. Three field experiments were conducted at the North Florida Research and Education Center in Quincy, FL, during the fall seasons of 2012, 2013, and 2014 to evaluate the efficacy of integrating grafting and ASM (Actigard 50 WG; acibenzolar-s-methyl (1,2,3-benzothiadiazole-7-thiocarboxylic acid-S-methyl-ester)) applications in reducing bacterial wilt disease and increasing marketable yield of tomatoes. Two tomato genotypes were used in the study: BHN 602, a bacterial wilt susceptible variety; and BHN 998, a bacterial wilt resistant hybrid rootstock (BHN Seed, Immokalee, FL). The grafted treatments consisted of BHN 602 grafted onto BHN 998 rootstocks.

In the 2012 experiment, the treatments were: nongrafted BHN 602 (nontreated); nongrafted BHN 602 treated with foliar ASM; a grafted control (nontreated); and grafted plants treated with foliar applications of ASM. A self-grafted control (i.e., grafting BHN 602 onto BHN 602) was not included in the study because the self-grafted control was previously shown by McAvoy et al. in 2012 to be statistically similar to nongrafted BHN 602 control in terms of disease incidence and marketable yield. In the 2013 and 2014 experiments, two additional treatments were added. These consisted of drip ASM applications given to both grafted and nongrafted BHN 602.

Seeds of BHN 602 and BHN 998 were sown in a peat vermiculite mixture (Metro mix, Sun Gro Horticulture Canada Ltd., Agawam, MA) and allowed to germinate and grow in polystyrene flats $(4.4 \times$ $4.4 \times 6.3 \mathrm{~cm}$ ) in a greenhouse, with temperatures ranging between a minimum of 20 to $24^{\circ} \mathrm{C}$ and maximum of 28 to $30^{\circ} \mathrm{C}$. Two weeks after seedling emergence, grafting was conducted using a modified Japanese tube graft technique (Rivard 2006; Kunwar et al. 2015). To make the graft, the seedlings having two to four true leaves and stem sizes of nearly $2 \mathrm{~mm}$ in diameter were selected. The bottom half of a rootstock seedling and top half of the scion seedling were cut at a 45-degree angle and attached so that the vascular tissue of the two meet and grow normally. Immediately after grafting, the grafted transplants were kept inside a healing chamber for 7 days in complete darkness and high relative humidity of 85 to $95 \%$. The conditions inside the healing chamber allow formation of callus necessary to reconnect the vascular bundles to provide water and nutrients to the scion and prevent scion from being water-stressed while the graft union between scion and rootstock is developing (Rivard and Louws 2006). In all of the experiments, a single greenhouse application of ASM $(50 \mathrm{mg} / \mathrm{liter})$ was given to the appropriate transplants 10 to 15 days after removing the plants from the grafting chamber, followed by weekly applications in the field after transplanting. In the greenhouse, ASM $(50 \mathrm{mg} / \mathrm{liter})$ was applied either as a foliar spray to the lower and upper leaf surfaces with a handheld sprayer (RL Flo-Master, Lowell, MI) until runoff, or as a soil drench by pouring $10 \mathrm{ml}$ of solution at the base of each plant. In the field, weekly ASM applications were made as follows: foliar sprays were applied using a pump-up back-pack sprayer (Fountain Head Group, Inc., New York Mills, NY), or a $\mathrm{CO}_{2}$-powered backpack sprayer (adjusted to $414 \mathrm{kPa}$ ) fitted with a boom to apply a $1-\mathrm{m}$ band with 178.6 micro molar $(\mu \mathrm{M})$ rate (equivalent to 35 grams/hectare in 378.5 liters of water); and drip applications at $178.6 \mu \mathrm{M}$ rate following supplemental labeling guidelines for ASM applications (Syngenta 2013).

Field inoculation for the 2012 experiment consisted of pouring $50 \mathrm{ml}$ of a $10^{6} \mathrm{CFU} / \mathrm{ml}$ bacterial suspension of Rs 5 strain in field irrigation water in each planting hole 5 days before transplanting to create a consistent inoculum load in each planting hole. The plants were transplanted to the field on 9 August, which was one day after the initial greenhouse ASM application. The initial field ASM application for this experiment was done on 16 August followed by four additional weekly applications on 23 and 31 August and 6 and 14 September. Each treatment consisted of four replications with 14 plants in each replication.

Field inoculations for both the 2013 and 2014 experiments were conducted by suspending bacterial cells of strain Rs5 in field irrigation water, adjusting the bacterial concentration to $10^{5} \mathrm{CFU} / \mathrm{ml}$, and then pouring $50 \mathrm{ml}$ of the suspension into each planting hole. As $R$. solanacearum is a good soil survivor (Granada and Sequeira 1983), the bacterial inoculum concentration used in the latter experiments (i.e., in 2013 and 2014) was reduced by one log unit below that was used in the 2012 experiment to reduce pathogen pressure in the soil. Field inoculation in the 2013 experiment was conducted on 19 August, which was 14 days before transplanting to the field; in the 2014 experiment, inoculum was applied on 8 August, 7 days before field transplanting.

For both of the experiments, plants were transplanted to the field 2 days after they were treated with ASM in the greenhouse. Each treatment in the 2013 experiment consisted of four replications with 17 plants in each replication and each treatment in the 2014 experiment consisted of four replications with 14 plants in each replication. The first field-ASM treatment for the 2013 experiment was conducted on 22 August followed by three more weekly applications on 28 August and 6 and 13 September. In the 2014 experiment, the first field-ASM treatment was applied on 12 August followed by four more weekly applications on 19 and 26 August and 2 and 8 September. The field plots were established on raised beds with dimensions $12.7 \mathrm{~cm}$ (tall) $\times 76.2 \mathrm{~cm}$ (wide) and spaced $1.8 \mathrm{~m}$ apart. Plants were spaced $50.8 \mathrm{~cm}$ within the row. The field soil was Norfolk sandy loam type (Thermic Typic Kandiudults) with pH 6.3. Beds were fumigated with chloropicrin (50\%) and methyl bromide $(50 \%)$ at a rate of $280 \mathrm{~kg}$ a.i./ha and covered with white polyethylene mulch following application of inorganic fertilizers as based on soil test results and cooperative extension recommendations (Olson and Santos 2012). In each of the experiments, before the bacterial inoculation and after transplanting, the plots were irrigated to field capacity via the drip-irrigation line established underneath the polyethylene mulch.

Bacterial wilt incidence data for each of the plots were recorded at weekly intervals as the percentage of wilted plants. Fruits were 
harvested from healthy plants twice in 2013 and in 2014, whereas in 2012 fruits were harvested only once because of the early frost event. Marketable yield of tomato fruits for each plot was recorded at harvest and graded according to USDA specifications (USDA-AMS 1991).

Statistical analysis. All of the field experiments were arranged in a randomized complete block design. All the statistical analyses were performed using JMP software of SAS (Version 12; SAS Institute Inc., Gary, NC). In the 2012 experiment, one-way ANOVA was conducted on the treatment combinations of "grafting" and "method of ASM application." Since experiments in 2013 and 2014 consisted of the same treatment combinations and were conducted with similar design, data from 2013 and 2014 field experiments were combined for analysis. The "treatments" were treated as fixed factors and "year" and "block nested within year" were treated as random factors. The percentage disease incidence and marketable yield across each fruit category were analyzed separately. The mean separation was conducted using Least Significant Difference (LSD) values at $P=0.05$ when needed.

In the 2014 experiment, one of the plots containing drip ASM treated grafted plants had significantly higher disease incidence (90.9\%). Upon close examination, almost all the plants in this plot were found to have their graft union in close proximity to the soil line which in turn led to the scion rooting. Since the scion rooting failed, the purpose of grafting (Tzortzakakis 2007), the disease incidence and yield values for this plot were replaced by missing values calculated using expectation-maximization (EM) algorithm of IBM SPSS Statistics Version 22, which provides a statistically consistent and unbiased missing value depending on the observed data (Dempster et al. 1977). Little's missing completely at random (Little's MCAR) test was run prior to EM analysis to verify that the data were missing at random (Little 1988).

\section{Results}

In the 2012 experiment, one-way ANOVA showed a significant effect of treatment combinations on the percentage disease incidence and marketable yield. All of the grafted plants with or without ASM application had significantly lower disease incidence and significantly higher total marketable yield than any of the nongrafted treatments (BHN 602 with or without ASM application) (Table 1). Within the grafted treatments, there was no statistical difference between disease incidence on grafted plants (nontreated) and grafted plants treated with foliar applications of ASM (Table 1). However, interestingly, the total marketable yield of foliar ASM-applied grafted plants was significantly lower than that of the nontreated grafted control (Table 1). The total yields of large and extra-large fruits of foliar ASM-applied grafted plants were also significantly lower than those from nontreated grafted control (Table 1). In the nongrafted treatment, both the disease incidence and total marketable yield of BHN 602 treated with foliar applications of ASM were statistically similar to nontreated BHN 602 control (Table 1).

The combined data from the 2013 and 2014 field experiments revealed a significantly lower total marketable yield of foliar ASMapplied grafted plants relative to nontreated grafted control. The marketable yields of large and extra large fruits of foliar ASM-applied grafted plants were also significantly less compared with nontreated grafted control (Table 2). This observation was in agreement with the results observed in the 2012 field experiment. The total marketable yield from grafted plants with foliar-applied ASM was also significantly

Table 1. Fruit yield (kg/ha) and percentage bacterial wilt (BW) incidence of susceptible tomato cultivar BHN 602 grafted onto resistant rootstock BHN 998 integrated with foliar applications of ASM $(178.6 \mu \mathrm{M})$. The experiment was conducted in the fall season of 2012 in Quincy, FL

\begin{tabular}{lccccc}
\hline & \multicolumn{4}{c}{ Marketable yield (kg/ha) $^{\mathbf{y}}$} & \multicolumn{2}{c}{ BW incidence $^{\mathbf{x}}$} \\
\cline { 2 - 5 } Treatment $^{\mathbf{w}}$ & Medium & Large & Extra large & Total & $(\%)$ \\
\hline Grafted (nontreated) & $3,383 \mathrm{a}^{\mathrm{z}}$ & $4,117 \mathrm{a}$ & $10,284 \mathrm{a}$ & $17,784 \mathrm{a}$ \\
Grafted + ASM (foliar) & $2,522 \mathrm{a}$ & $2,244 \mathrm{~b}$ & $5,768 \mathrm{~b}$ & $10,535 \mathrm{~b}$ & $11.9 \mathrm{~b}$ \\
BHN 602 (nontreated) & $448 \mathrm{~b}$ & $352 \mathrm{c}$ & $165 \mathrm{c}$ & $966 \mathrm{c}$ & $28.0 \mathrm{~b}$ \\
BHN 602 + ASM (foliar) & $492 \mathrm{~b}$ & $346 \mathrm{c}$ & $278 \mathrm{c}$ & $1,116 \mathrm{c}$ & $7.5 \mathrm{a}$ \\
Pr $>$ F & 0.0037 & $<0.0001$ & 0.0005 & 0.0002 & 0.0001 \\
\hline
\end{tabular}

${ }^{\mathrm{w}}$ Each entry consisted of 4 replications with 14 plants in each replication, and the experiment was arranged as a randomized complete block design.

${ }^{x}$ Percentage bacterial wilt incidence before harvest. Field was inoculated with $50 \mathrm{ml}$ of $10^{6} \mathrm{CFU} / \mathrm{ml}$ of $R$. solanacearum Rs 5 strain in each planting hole, 5 days before transplanting. The effect of the treatments on the BW incidence data were analyzed separately with one-way ANOVA at $P=0.05$

y Marketable yield of tomato fruits recorded at harvest and graded according to USDA specifications. The effect of the treatments on the marketable yield were analyzed separately with one-way ANOVA at $P=0.05$.

${ }^{z}$ Column means followed by the same letter do not differ significantly at $P=0.05$ based on Least Significant Difference (LSD).

Table 2. Fruit yield (kg/ha) and percentage bacterial wilt (BW) incidence of susceptible tomato cultivar BHN 602 grafted onto resistant rootstock BHN 998 integrated with foliar and drip applications of ASM $(178.6 \mu \mathrm{M})$. The experiments were conducted in the fall season of 2013 and 2014 in Quincy, FL

\begin{tabular}{|c|c|c|c|c|c|}
\hline \multirow[b]{2}{*}{ Treatment $^{\mathrm{w}}$} & \multicolumn{4}{|c|}{ Marketable yield $(\mathrm{kg} / \mathrm{ha})^{\mathrm{y}}$} & \multirow{2}{*}{$\frac{\text { BW incidence }}{(\%)}$} \\
\hline & Medium & Large & Extra large & Total & \\
\hline Grafted (nontreated) & $8,049 \mathrm{a}^{\mathrm{z}}$ & $11,779 \mathrm{a}$ & $23,581 \mathrm{a}$ & 43,408 a & $20.9 \mathrm{c}$ \\
\hline Grafted + ASM (drip) & $8,025 \mathrm{a}$ & $11,770 \mathrm{a}$ & $22,535 \mathrm{a}$ & $42,330 \mathrm{a}$ & $14.2 \mathrm{c}$ \\
\hline Grafted + ASM (foliar) & $6,074 \mathrm{ab}$ & $7,569 \mathrm{~b}$ & $13,118 \mathrm{~b}$ & $26,761 \mathrm{~b}$ & $22.6 \mathrm{c}$ \\
\hline BHN 602 (nontreated) & $3,914 \mathrm{bc}$ & $4,288 \mathrm{bc}$ & $7,112 b c$ & $15,314 \mathrm{bc}$ & $67.8 \mathrm{a}$ \\
\hline BHN $602+$ ASM (drip) & $3,887 \mathrm{bc}$ & $4,708 \mathrm{bc}$ & $7,671 \mathrm{bc}$ & $16,266 \mathrm{bc}$ & $44.5 \mathrm{~b}$ \\
\hline BHN 602 + ASM (foliar) & $2,138 \mathrm{c}$ & $2,592 \mathrm{c}$ & $3,747 \mathrm{c}$ & $8,478 \mathrm{c}$ & $57.8 \mathrm{ab}$ \\
\hline $\operatorname{Pr}>F$ & 0.0002 & $<0.0001$ & $<0.0001$ & $<0.0001$ & $<0.0001$ \\
\hline
\end{tabular}

${ }^{w}$ Each entry consisted of 4 replications with 17 plants (in 2013) and 14 plants (in 2014) in each replication, and the experiment was arranged as a randomized complete block design.

x Percentage bacterial wilt incidence before harvest. Field was inoculated with $R$. solanacearum Rs5 strain with $50 \mathrm{ml}$ of $10^{5} \mathrm{CFU} / \mathrm{ml}$ in each planting hole $1-2$ weeks before transplanting. The effect of the treatments on the BW incidence data from the 2013 and 2014 experiments were analyzed with two-way ANOVA using year, treatments and interaction as independent factors. The effect of interaction of two independent factors was nonsignificant at $P=0.05$. Therefore, the BW incidence data from the 2013 and 2014 experiments were combined for analysis.

y Marketable yield of tomato fruits recorded at harvest and graded according to USDA specifications. The effect of the treatments on the marketable yield data from the 2013 and 2014 experiments were analyzed with two-way ANOVA using year and treatments as independent factors. The effect of interaction of two independent factors were nonsignificant at $P=0.05$. Therefore, the marketable fruit yield data from the 2013 and 2014 experiments were combined for analysis.

${ }^{z}$ Column means followed by the same letter do not differ significantly at $P=0.05$ based on Least Significant Difference (LSD). 
lower than grafted plants with drip-applied ASM (Table 2). However, in terms of disease incidence, foliar ASM-applied grafted plants were not statistically different than drip ASM-applied grafted plants or nontreated grafted control (Table 2). Grafting alone or in combination with drip applications of ASM significantly reduced disease incidence and increased total marketable yield relative to all nongrafted treatments (Table 2). Unlike foliar applications of ASM which significantly reduced the marketable yield of grafted plants, drip applications of ASM had no significant effect on the total marketable yield of grafted plants across any of the fruit size categories (Table 2). Within the nongrafted treatments, applications of ASM, whether as foliar spray or through drip irrigation lines, did not significantly affect the total marketable yield relative to nontreated BHN 602 control. Also, there was no significant difference between foliar and drip applications of ASM applied to nongrafted BHN 602 in terms of disease incidence or total marketable yield (Table 2). Foliar applications of ASM showed no significant effect on the disease incidence of BHN 602 whereas drip applications of ASM significantly reduced disease incidence on BHN 602.

\section{Discussion}

This is the first study evaluating the impact of integrated use of ASM and grafted plants for the management of bacterial wilt disease in tomato. The findings demonstrate the significant reduction of total marketable yield of foliar ASM-applied grafted plants, compared with nontreated grafted control, when ASM is applied weekly at a concentration of $178.6 \mu \mathrm{M}$. Intense use of foliar applications of ASM has been previously reported to cause reduction in growth and yield of plants in the field (Graham and Myers 2011; Louws et al. 2001; Romero et al. 2001). For example, in pepper, foliar applications of ASM at weekly intervals with concentrations of 17 or $35 \mathrm{~g}$ ai/ha when applied to control bacterial spot disease (Xanthomonas axonopodis pv. vesicatoria) were found to significantly reduce yield (Romero et al. 2001). Similarly, in tomato, a statistically nonsignificant but numerically consistent reduction in yield was reported in a majority of the bacterial spot-infected tomato plots treated with foliar applications of ASM (35 g ai/ha) as compared with those treated with standard fungicide program (Louws et al. 2001). ASM acts by inducing SAR in plants that confers long-lasting broad-spectrum protection against a wide spectrum of plant pathogens and is accompanied by coordinated expression of specific pathogenesis-related (PR) genes (Tally et al. 1999). The reduction in yield observed in foliar ASM-applied grafted plants relative to nontreated grafted plants may be attributed to the physiological compensation resulting from excessive and constitutive induction of plant defense when ASM was applied as a foliar spray as reported previously (Huang et al. 2012; Romero et al. 2001; van Loon et al. 2006; Walters and Fountaine 2009). Our hypothesis that the induction of SAR in the upper part of the plant might have resulted in the trade-off of nutrients and resources away from the developing fruits therefore seems valid based on published literatures (Graham et al. 2011; Louws et al. 2001; Romero et al. 2001). The disease incidence or total marketable yield of the nongrafted plants treated with foliar applications of ASM was statistically similar to that of nontreated nongrafted BHN 602 control. This observation was consistent with the findings by Pradhanang et al. (2005), who also demonstrated the inability of foliar applications of ASM to significantly control bacterial wilt incidence or improve yield in a susceptible tomato cultivar.

Unlike foliar ASM-applied grafted plants, which had significantly reduced total yield relative to nontreated grafted control, drip ASMapplied grafted plants had no statistical difference in total yield relative to the nontreated grafted control. Therefore, drip applications of ASM seem to be the only acceptable ASM application method on grafted tomato plants in the fields with a history of $R$. solanacearum as opposed to foliar ASM applications. However, since the total marketable yield of the drip ASM-applied grafted plants was not significantly better than that of grafted plants, the cost effectiveness of combining drip ASM applications with grafting in a commercial production system seems questionable at the dose of ASM used in the study. This study was conducted only with one concentration of ASM at one frequency of application. Previous studies have shown that modifying rates and frequencies of ASM applications may help improve the efficacy of ASM in tomato against other diseases in the field such as bacterial spot of tomato (de Carvalho Pontes et al. 2016; Huang et al. 2012). Drip application of Actigard is labeled in the United States for controlling bacterial spot (Xanthomonas spp.) and bacterial speck (Pseudomonas syringae pv. tomato) of tomato (Syngenta 2013), two of the important bacterial diseases of tomato in Florida. Grafting, on the other hand, has been shown to effectively manage root-knot nematodes (Meloidogyne spp.) (Kunwar et al. 2015; Rivard et al. 2010), southern blight (Sclerotium rolfsii) (Rivard et al. 2010), Fusarium wilt (Fusarium oxysporum f.sp. lycopersici), and Verticillium wilt (Verticillium dahlia) (Louws et al. 2010; Rivard 2006). This study further demonstrated the ability of grafting to effectively control bacterial wilt disease of tomato with significant improvement in total marketable yield compared with nongrafted control, thereby validating the findings from several recent studies conducted in the United States (McAvoy et al. 2012; Rivard and Louws 2008). The rootstock BHN 998 used in the study was demonstrated to impart resistance to root-knot nematodes (Meloidogyne spp.), another important pathogen affecting tomato production in southeastern United States. (Kunwar et al. 2015; Rivard et al. 2010). Therefore, considering the additional benefits of grafting and drip applications of ASM against several other plant pathogens mentioned above, the integration of the two seems prudent for controlling multiple tomato diseases in the field. Optimizing the application frequency and rate may improve the overall effectiveness of drip applications of ASM onto the grafted plants against multiple pathogens in the field, possibly improving yield and economics. Further studies to test the profitability and effectiveness of this integrated approach for controlling multiple diseases in Florida, such as bacterial spot and root-knot nematodes along with bacterial wilt of tomato, will provide additional critical information for growers using grafted tomato plants in their production system.

\section{Acknowledgments}

This project has been funded by the Dean for Research, Institute of Food and Agricultural Sciences, University of Florida; and the United States Department of Agriculture SCRI grant (2011-51181-30963). The authors would also like to thank David Walker for kind review and Jackie Snell and farm crew members of North Florida Research and Education Center, University of Florida, Quincy, for helping in conducting the field experiments. The authors would also like to acknowledge the support of Yonas Kefialew, Amanda Strayer, Dev Paudel, and Thu Nga Nguyen for their valuable suggestions and support.

\section{Literature Cited}

de Carvalho Pontes, N., dos Reis Nascimento, A., Golynski, A., Maffia, L. A., de Oliveira, J. R., and Quezado-Duval, A. M. 2016. Intervals and number of applications of acibenzolar-s-methyl for the control of bacterial spot on processing tomato. Plant Dis. 100:2126-2133.

Dempster, A. P., Laird, N. M., and Rubin, D. B. 1977. Maximum likelihood from incomplete data via the EM algorithm. J. R. Stat. Soc. B 39:1-38.

Enfinger, J., McCarter, S., and Jaworski, C. 1979. Evaluation of chemicals and application methods for control of bacterial wilt of tomato transplants. Phytopathology 69:637-640.

Fegan, M., and Prior, P. 2005. How complex is the "Ralstonia solanacearum species complex"? Pages 449-461 in: Bacterial Wilt Disease and the Ralstonia solanacearum Species Complex. C. Allen, P. Prior, and A. C. Hayward, eds. American Phytopathological Society, St. Paul, MN.

Gan, J., Yates, S., Ernst, F., and Jury, W. 2000. Degradation and volatilization of the fumigant chloropicrin after soil treatment. J. Environ. Qual. 29:1391-1397.

Graham, J., and Lloyd, A. B. 1979. Survival of potato strain (race 3) of Pseudomonas solanacearum in the deeper soil layers. Aust. J. Agric. Res. 30:489-496.

Graham, J. H., and Myers, M. E. 2011. Soil application of SAR inducers imidacloprid, thiamethoxam, and acibenzolar-S-methyl for citrus canker control in young grapefruit trees. Plant Dis. 95:725-728.

Granada, G., and Sequeira, L. 1983. Survival of Pseudomonas solanacearum in soil, rhizosphere, and plant roots. Can. J. Microbiol. 29:433-440.

Hayward, A. 1991. Biology and epidemiology of bacterial wilt caused by Pseudomonas solanacearum. Annu. Rev. Phytopathol. 29:65-87.

Hayward, A. C. 1994. The host of Pseudomonas solanacearum. Pages 9-24 in: Bacterial Wilt: The disease and its causative agent, Pseudomonas solanacearum A. C. Hayward and G. L., Hartman, eds. CAB International, Wallingford, U.K.

Hong, J. C., Momol, M. T., Jones, J. B., Ji, P. S., Olson, S. M., Allen, C., Perez, A., Prakash, P., and Guven, K. 2008. Detection of Ralstonia solanacearum in irrigation ponds and aquatic weeds associated with the ponds in North Florida. Plant Dis. 92:1674-1682.

Hong, J. C., Norman, D. J., Reed, D. L., Momol, M. T., and Jones, J. B. 2012 Diversity among Ralstonia solanacearum strains isolated from the southeastern United States. Phytopathology 102:924-936. 
Huang, C.-H., Vallad, G. E., Zhang, S., Wen, A., Balogh, B., Figueiredo, J. F. L., Behlau, F., Jones, J. B., Momol, M. T., and Olson, S. M. 2012. Effect of application frequency and reduced rates of acibenzolar-S-methyl on the field efficacy of induced resistance against bacterial spot on tomato. Plant Dis. 96: 221-227.

Ji, P., Allen, C., Sanchez-Perez, A., Yao, J., Elphinstone, J. G., Jones, J. B., and Momol, M. T. 2007. New diversity of Ralstonia solanacearum strains associated with vegetable and ornamental crops in Florida. Plant Dis. 91:195-203.

Ji, P., Momol, M., Olson, S., Pradhanang, P., and Jones, J. 2005. Evaluation of thymol as biofumigant for control of bacterial wilt of tomato under field conditions. Plant Dis. 89:497-500.

Jones, J. B., Zitter, T. A., Momol, T. M., and Miller, S. A. 2014. Pages 58-60 in: Compendium of Tomato Diseases and Pests, 2nd Ed. APS Press, St. Paul, MN.

Kelman, A. 1954. The relationship of pathogenicity of Pseudomonas solanacearum to colony appearance in a tetrazolium medium. Phytopathology 44:693-695.

King, S. R., Davis, A. R., Liu, W., and Levi, A. 2008. Grafting for disease resistance. HortScience 43:1673-1676.

Kunwar, S., Paret, M. L., Olson, S. M., Ritchie, L., Rich, J. R., Freeman, J., and McAvoy, T. 2015. Grafting using rootstocks with resistance to Ralstonia solanacearum against Meloidogyne incognita in tomato production. Plant Dis. 99:119-124.

Lebeau, A., Daunay, M.-C., Frary, A., Palloix, A., Wang, J.-F., Dintinger, J., Chiroleu, F., Wicker, E., and Prior, P. 2011. Bacterial wilt resistance in tomato, pepper, and eggplant: genetic resources respond to diverse strains in the Ralstonia solanacearum species complex. Phytopathology 101:154-165.

Little, R. J. 1988. A test of missing completely at random for multivariate data with missing values. J. Am. Stat. Assoc. 83:1198-1202.

Louws, F., Wilson, M., Campbell, H., Cuppels, D., Jones, J., Shoemaker, P., Sahin, F., and Miller, S. 2001. Field control of bacterial spot and bacterial speck of tomato using a plant activator. Plant Dis. 85:481-488.

Louws, F. J., Rivard, C. L., and Kubota, C. 2010. Grafting fruiting vegetables to manage soilborne pathogens, foliar pathogens, arthropods and weeds. Sci. Hortic. (Amsterdam) 127:127-146.

Mansfield, J., Genin, S., Magori, S., Citovsky, V., Sriariyanum, M., Ronald, P., Dow, M., Verdier, V., Beer, S. V., and Machado, M. A. 2012. Top 10 plant pathogenic bacteria in molecular plant pathology. Mol. Plant Pathol. 13:614-629.

McAvoy, T., Freeman, J., Rideout, S., Olson, S. M., and Paret, M. L. 2012. Grafting using hybrid rootstocks for management of bacterial wilt in field tomato production. HortScience 47:621-625.

McCarter, S. M. 1991. Bacterial wilt. Pages 28-29 in: Compendium of Tomato Diseases. J. B. Jones, J. P. Jones, R. E. Stall, and T. A. Zitter, eds. American Phytopathological Society, St. Paul, MN.

Momol, T., Ji, P., Jones, J. B., and Olson, S. 2005. Recommended management strategies for bacterial wilt on tomato caused by Ralstonia solanacearum. NFREC Ext. Rpt. 2005-8, Univ. of Florida, Quincy.

Olson, S. M., and Santos, B. 2012. Vegetable Production Handbook for Florida 2010-2011. Florida Coop. Serv., Univ. of Florida. Vance Pub. Corp., Mexico, MO.

Pradhanang, P., Ji, P., Momol, M., Olson, S., Mayfield, J., and Jones, J. 2005. Application of acibenzolar-S-methyl enhances host resistance in tomato against Ralstonia solanacearum. Plant Dis. 89:989-993.

Pradhanang, P. M., Elphinstone, J. G., and Fox, R. T. V. 2000. Identification of crop and weed hosts of Ralstonia solanacearum biovar 2 in the hills of Nepal. Plant Pathol. 49:403-413.

Rivard, C. L. 2006. Grafting tomato to manage soilborne diseases and improve yield in organic production systems. Masters thesis. North Carolina State University, Raleigh, NC.
Rivard, C. L., and Louws, F. J. 2006. Grafting for disease resistance in heirloom tomatoes. Publ. AG-675, NC Coop. Ext. Serv., Raleigh, NC.

Rivard, C. L., and Louws, F. J. 2008. Grafting to manage soilborne diseases in heirloom tomato production. HortScience 43:2104-2111.

Rivard, C. L., O'Connell, S., Peet, M. M., and Louws, F. J. 2010. Grafting tomato with interspecific rootstock to manage diseases caused by Sclerotium rolfsii and southern root-knot nematode. Plant Dis. 94:1015-1021.

Rivard, C. L., O'Connell, S., Peet, M. M., Welker, R. M., and Louws, F. J. 2012. Grafting tomato to manage bacterial wilt caused by Ralstonia solanacearum in the southeastern United States. Plant Dis. 96:973-978.

Romero, A. M., Kousik, C. S., and Ritchie, D. F. 2001. Resistance to bacterial spot in bell pepper induced by acibenzolar-S-methyl. Plant Dis. 85:189-194.

Safni, I., Cleenwerck, I., De Vos, P., Fegan, M., Sly, L., and Kappler, U. 2014. Polyphasic taxonomic revision of the Ralstonia solanacearum species complex: proposal to emend the descriptions of Ralstonia solanacearum and Ralstonia syzygii and reclassify current $R$. syzygii strains as Ralstonia syzygii subsp. syzygii subsp. nov., $R$. solanacearum phylotype IV strains as Ralstonia syzygii subsp. indonesiensis subsp. nov., banana blood disease bacterium strains as Ralstonia syzygii subsp. celebesensis subsp. nov. and $R$. solanacearum phylotype I and III strains as Ralstonia pseudosolanacearum sp. nov. Int. J. Syst. Evol. Microbiol. 64:3087-3103.

Santos, B. M., Gilreath, J. P., Motis, T. N., Noling, J. W., Jones, J. P., and Norton, J. A. 2006. Comparing methyl bromide alternatives for soilborne disease, nematode and weed management in fresh market tomato. Crop Prot 25:690-695.

Scott, J., Jones, J., Somodi, G., Chellemi, D., and Olson, S. 1995. 'Neptune', a heat-tolerant, bacterial-wilt-tolerant tomato. HortScience 30:641-642.

Syngenta. 2013. Actigard Supplemental labeling: Drip/overhead irrigation, SCP 922AS5 0513. Syngenta Crop Prot., Greensboro, NC. http://www.syngentacropprotection com/pdf/special/scp922as50513.pdf

Tally, A., Oostendorp, M., Lawton, K., Stub, T., Bassi, B., Agrawal, A. A., Tuzun, S., and Bent, E. 1999. Commercial development of elicitors of induced resistance to pathogens. Pages 357-369 in: Induced Plant Defenses Against Pathogens and Herbivores, Biochemistry, Ecology, and Agriculture. A. A. Agrawal, S. Tuzun, and E. Bent, eds. American Phytopathological Society, St. Paul, MN.

Tzortzakakis, E. 2007. A case of infection on the scion of grafted tomatoes by the root-knot nematode Meloidogyne javanica. Acta Agric. Slov. 89:103.

UNEP. 2011. The Montreal protocol on substances that deplete the ozone layer. Ozone Secretariat, Vienna Convention for the Protection of the Ozone Layer UN Env. Prog. (UNEP), Nairobi, Kenya.

USDA-AMS. 1991. United States standards for grades of fresh tomatoes. USDA Agricultural Marketing Service, Washington, DC.

USDA-NASS. 2016. Vegetables 2015 Summary. USDA National Agricultura Statistics Service, Washington, DC. http://usda.mannlib.cornell.edu/usda/nass/ VegeSumm//2010s/2016/VegeSumm-02-04-2016.pdf

Vallad, G. E., and Goodman, R. M. 2004. Systemic acquired resistance and induced systemic resistance in conventional agriculture. Crop Sci. 44: 1920-1934.

van Elsas, J. D., Kastelein, P., van Bekkum, P., van der Wolf, J. M., de Vries, P. M. and van Overbeek, L. S. 2000. Survival of Ralstonia solanacearum biovar 2, the causative agent of potato brown rot, in field and microcosm soils in temperate climates. Phytopathology 90:1358-1366.

van Loon, L. C., Rep, M., and Pieterse, C. 2006. Significance of inducible defenserelated proteins in infected plants. Annu. Rev. Phytopathol. 44:135-162.

Walters, D., and Fountaine, J. 2009. Practical application of induced resistance to plant diseases: an appraisal of effectiveness under field conditions. J. Agric. Sci. 147:523-535. 